\title{
Two Notes on the Papyri of the Shepherd of Hermas
}

\author{
Dan Batovici*
}

\begin{abstract}
The following reasseses the validity of the argument according to which in the Egyptian transmission of the Shepherd of Hermas the first four visions have circulated separately from the rest of the book. It is also shown that four fragments sometimes thought to be of to two manuscripts do not belong toghether.
\end{abstract}

Keywords: Shepherd of Hermas, Egyptian transmission, grouping papyri fragments

DOI 10.1515/apf-2016-0025

This short article calls into question a long standing assumption concerning the Egyptian circulation of the Shepherd of Hermas which was based on the reconstruction of P.Mich. 2.2.129, and the similar claim with regard to P.Bodmer 38. An additional note confirms that P.Berol inv. 6789 and P.Amh. 2.190 are not of the same codex, and offers a fresh argument that the same is true for P.Oxy. 15.1828 and P.Oxy. 15.1783, despite the fact that this has been suggested in older as well as more recent scholarship.

\section{Do the Papyri Reflect a A Separate Circulation of Vis. 1-4 and of Vis. 5-Sim. 10 in Egypt?}

P.Mich. 2.2.129 (LDAB 1097) is an exceptionally preserved papyrus codex of the Shepherd of Hermas, compared to the highly fragmentary

Vorbemerkung: I am grateful for the feedback I received from Willy Clarysse, Joseph Verheyden, and the editors of the Journal. This research was made possible through the generous help of a FLOF grant from the Faculty of Theology and Religious Studies at KU Leuven.

* Kontakt: Dan Batovici, KU Leuven, Sint-Michielsstraat 4, Box 3101, B-3000 Leuven, <dan.batovici@yahoo.com> 
state of most of this writing's other papyri: no less than 62 pages are extant, some quite damaged (a few still unplaced) and others almost complete, written in a sloping severe style. ${ }^{1}$ Since many page numbers have survived, it is possible to establish that the first surviving page, containing Sim. 2.8-3.3 [51-52], was numbered 55. ${ }^{2}$

Notoriously within Hermas studies, C. Bonner proposed that P.Mich. 2.2.129 would have started with Vision 5, and not with Vision 1 of the Shepherd, reflecting the separate circulation in Egypt of the first four Visions on the one hand, and of the rest of the book starting with Vision 5 on the other hand. This particular proposal - and exceptionally precise, considering that Vis. 5 is a quite short text - proved successful to the point that it is sometimes considered common knowledge and used as ground for further reasoning for the transmission of the book in Egypt. ${ }^{3}$

Bonner's argument is developed in two steps. First, based on the number of lines per page (normally 30-32, but otherwise ranging from 27 to 34 ) and letters per line (from 15 to 23), Bonner estimates that page 1 would have contained either the end of Mand. 4.1 or the beginning of Mand. 4.2. This leads him to rule out the possibility that page 1 could have started with the beginning of Mand. 4.1., and furthermore to infer that "page 1, therefore, was not the first page of the manuscript. ... We must conclude that several leaves had been lost from the beginning of our codex before the page-numbers were added." 4

In a second step building on the first he then tries to ground the proposal that the initial manuscripts must have started with Vision 5 which is

\footnotetext{
${ }^{1}$ First published in C. Bonner, A Papyrus Codex of the Shepherd of Hermas (Similitudes 2-9), with a Fragment of the Mandates (Ann Arbor: University of Michigan Press, 1934). Bonner published in advance a description and important variant readings in C. Bonner, "A Papyrus Codex of the Shepherd of Hermas," HTR 18/2 (1925), 115-127. Digital images are available online at <http://quod.lib.umich.edu/a/apis?type=boolean; view=thumbnail;rgn1=apis_inv;q1=P.Mich.inv.\%2520917>.

${ }^{2}$ Bonner, "A Papyrus Codex of the Shepherd," 117.

${ }^{3}$ See for example R. Joly, Hermas: Le pasteur (SC 53 bis; Paris: Cerf, ${ }^{2} 2011$ ), 15; G.F. Snyder, The Shepherd of Hermas (The Apostolic Fathers 6; London: Thomas Nelson \& Sons, 1968), 4; A. Carlini, "La tradizione testuale del Pastore di Erma e i nuovi papiri," in Le strade del testo, edited by G. Cavallo (Lecce: Adriatica Editrice, 1987), 23-43, at 32-34; J.J. Ayán Calvo, Hermas: El Pastor (Fuentes Patrísticas 6; Madrid: Ciudad Nueva, 1995), 23-24; C. Osiek, The Shepherd of Hermas: A Commentary (Hermeneia; Minneapolis: Fortress Press, 1999), 3.

${ }^{4}$ Bonner, "A Papyrus Codex of the Shepherd," 118.
} 
taken as an introduction to the Mandates, ${ }^{5}$ for which he presupposes 6 lost leafs before page 1. It is important to quote Bonner at this point, as it is relevant for the manner in which he argues his point:

The middle left-hand page of the surviving portion of the manuscript (p. 86) ends in Sim VII. 3, near the end of the section. Now this is exactly the middle point of that portion of the Shepherd which is contained between the beginning of Vis. V and the end of the whole work, as may be seen by a glance at the edition minor of Gebhardt, Harnack, and Zahn, which is closely printed and has no footnotes to disturb the equality of the pages. Thus the middle point of our quire is probably the middle point of the whole manuscript. This confirms the view that the whole manuscript consisted of one very large gathering of double leaves. In such a book any loses are likely to be exactly equalled at the end, for the second half on an outer double-sheet would scarcely remain in place after the first had been torn away. On this supposition the injured book at the time when page number of leaves after the middle as before it, and we may calculate that the last page (p. 172) would end somewhere in Sim. IX. 30, a point which is about as far from the end of the whole work as page 1 is from the beginning of Vis. V. ${ }^{6}$

To begin with, I would note that while Bonner's first step is an estimation based on the page numbers in the manuscript, the second one has no ground whatsoever in the artefact. The point of reference for Bonner's calculations is a printed edition instead; this is important to keep in mind, especially given that the identification of Vision 5 as the beginning of the codex, no less than 65 pages away from the extant fragments - the 54 pages lost before the extant page 55, and the 11 or 12 presupposed by Bonner - is a strikingly precise proposal. That particular Vision covers little more than one page of a Loeb Classical Library edition. One page away, the first Mandate would have been an equally grounded candidate.

I return now to Bonner's first step, namely his estimation that page 1 would have had on it the end of Mand. 4.1 or the beginning of Mand. 4.2, and that the beginning of Mand. 4 is out of the question. Using the word count feature of a word processor one can count the number of characters in a modern edition of the Shepherd. Conversely, if one can estimate the

\footnotetext{
${ }^{5}$ Bonner, "A Papyrus Codex of the Shepherd," 118.

${ }^{6}$ Bonner, "A Papyrus Codex of the Shepherd," 118.
} 
quantity of letters that goes on a page and the number of pages is known, then it is possible to see how much of the Shepherd those pages could have contained by using the characters-with-no-spaces-count feature of the word processor. Bonner notes that the number of lines per page is normally 30 , but also that many are 31 and 32, and that they can go as low as 27 and as high as 34; furthermore, that the letters per line vary from 15 to $23 .{ }^{7}$ If we take the average of 30 lines per page and multiply it with 54 (the number of missing pages according to the extant numbering) and the result with the maximum of 34 , respectively with the minimum of 27 letters per line, the two numbers we end up with indicate that on the first page there could have been anything from Mand. 3.1 [28] to Mand. 7.1 [37]. If we use the extreme numbers of lines per page-27 and 34-and go through the same computations, the new numbers we end up with indicate that on page 1 there could have been anything from Vision 4.2 [23.2] to Mand. 9.1 [39].

To be sure, these calculations are not meant to lead to a different reconstruction; they serve to show just how weakly grounded is Bonner's first step, and even more so his second step: the move beyond what would have been page 1 in the manuscript, hypothesizing that "eleven or twelve pages" 8 were lost before the page numbering was written, and that the first of them started with Vision 5. For one, the former of the last two results indicate that, should one like to argue for the Vision 5 as the beginning, the postulation of leaves lost before the numbering is not really necessary. All in all, what this calculations show is that while it is possible that page 1 did not have Vision 1 on it, it is impossible to establish with any degree of certainty that it is one precise chapter of the book.

In the light of this, the following statement from the 1934 edition seems overly confident and potentially misleading: "[P.Mich. 2.2.129] has been shown to have included the Mandates and the Similitudes, and doubtless what is now called Vision 5 introduced the whole." Bonner then attempts to gather some external evidence for the division of the Shepherd before the fifth Vision, ${ }^{10}$ but the only direct evidence that is proposed for that is P.Mich. 2.2.129. The evidence that comes closest is perhaps the Vulgate version of the Shepherd, of which he notes that "the Old Latin version has

\footnotetext{
${ }^{7}$ Bonner, "A Papyrus Codex of the Shepherd," 118.

${ }^{8}$ Bonner, "A Papyrus Codex of the Shepherd," 118.

${ }^{9}$ Bonner, A Papyrus Codex of the Shepherd, 13; emphasis added.

${ }^{10}$ Bonner, A Papyrus Codex of the Shepherd, 13-14.
} 
visio quinta initium pastoris." ${ }^{11}$ However, the apparatus of the latest edition of the Hermas Vulgate shows somewhat longer readings: visio quinta initium pastoris nuntii penitentiae, ${ }^{12}$ which may at least suggest that the Shepherd intended here is the character, not the book. In this event, this would be simply a subtitle indicating that it is in this fifth vision that the Shepherd is introduced, as is indeed the case.

I hope I have raised enough doubt about this reconstruction, and should like to conclude therefore that P.Mich. 2.2.129 cannot be used as evidence for the separate circulation in Egypt of the first four Visions on the one hand, and of the rest of the book starting with Vision 5 on the other hand.

P.Bodmer 38 (LDAB 1106) poses a similar problem. It is part of the so called "Codex of Visions," which is a late fourth, early fifth century single-quire, one column codex, hosted in the Bodmer collection in Geneva. ${ }^{13}$ It contains the first three visions of the Shepherd of Hermas (and these leaves are designated as P.Bodmer 38), a fourth century work named the Vision of Dorotheos, and a number of Christian poems. They have been edited separately, first the Vision of Dorotheus, ${ }^{14}$ then the Shepherd, and lastly the poems. ${ }^{15}$ The codex measures about $17.5 \times 28.5$ centimetres, and is written single-column throughout.

At the time the Vision of Dorotheus was published, it was thought to be the first work in the codex. The surviving leaves were separated when they reached the Bodmer collection and had no numbering; as a result, the reconstruction of the codex published as an appendix to the Bibliotheca

\footnotetext{
${ }^{11}$ Bonner, A Papyrus Codex of the Shepherd, 14.

${ }^{12}$ C. Tornau and P. Cecconi, eds., The Shepherd of Hermas in Latin: Critical Edition of the Oldest Translation Vulgata (TU 173; Berlin: De Gruyter, 2014), at 57.

${ }^{13}$ First published in A. Carlini, Papyrus Bodmer XXXVIII: Erma, Il Pastore (Ia-IIIa visione) (BB.SP; Cologny/Genève: Fondation Bodmer, 1991), containing black and white images. A more recent edition is available in T.A. Wayment, The Text of the New Testament Apocrypha (100-400) (New York/London: Bloomsbury, 2013), 85-104, with useful colour images at 289-312.

${ }^{14}$ A. Hurst/O. Reverdin/J. Rudhardt, Papyrus Bodmer XXIX: Vision de Dorotheos (BB.SP; Cologny/Genève: Fondation Bodmer, 1984). This was then re-edited in A.H.M. Kessels and P.W. van der Horst, "The Vision of Dorotheus (Pap. Bodmer 29), Edited with Introduction, Translation and Notes," VC 41 (1987), 313-359.

15 A. Hurst and J. Rudhardt, Papyri Bodmer XXX-XXXVII: "Codex des Visions," Poèmes divers (BB.SP; Munich: Fondation Bodmer, 1999).
} 
Bodmeriana volume places the Shepherd at the end. ${ }^{16}$ However, in response to some critique formulated - in private, it seems - by J. van Haelst, the reconstruction was reformulated in the Hermas volume, in collaboration with van Haelst. ${ }^{17}$ The new reconstruction reveals a single quire-codex codex in which the succession of horizontal and vertical fibres is the regular one: $\downarrow \rightarrow$ until the middle of the quire, then $\rightarrow \downarrow$ until the end. There are 22 surviving leaves, and the reconstructed codex would have had 24 leaves or 12 bifolia or 48 pages. The Shepherd of Hermas covers eleven extant leaves - designated as P.Bodmer 38 - of which the first and third are very fragmentary; there are also 13 unplaced fragments. It is supposed to have had two more leaves, the bifolium that would have been the middle opening. ${ }^{18}$

The extant text of the Shepherd of Hermas in P.Bodmer 38 stops at Vis. 3.13.4 [21]. The question would be how much of Hermas was initially copied into the "Codex of Visions." Carlini suggests that it probably ended with the fourth Vision (for which a bifolium in the middle would have been necessary in his view), but does not exclude the possibility that "il fascicolo fosse più corposo." 19

Kasser, Cavallo and van Haelst concur that there are six scribes at work in the "Codex of Visions," and the Shepherd is written by two scribes: A who wrote the first five leaves, and $\mathrm{B}$ who wrote leaves 6 to $11 .{ }^{20}$ On the

\footnotetext{
${ }^{16}$ R. Kasser and G. Cavallo, "Description et datation du Codex des Visions," in A. Hurst/ O. Reverdin/J. Rudhardt, Papyrus Bodmer XXIX: Vision de Dorotheos (BB.SP; Cologny/Genève: Fondation Bodmer, 1984), 99-120, at 101.

${ }^{17}$ R. Kasser, G. Cavallo, and J. van Haelst, "Nouvelle description du Codex des Visions," in A Carlini. Papyrus Bodmer XXXVIII: Erma, Il Pastore (Ia-IIIa visione) (BB. SP; Cologny/ Genève: Fondation Bodmer, 1991), 103-128, at 107.

${ }^{18}$ The Vision of Dortheus covers five further leaves - 14-18, designated as P.Bodmer 29 - with a minimally decorated title in the centre of the top margin on the $\rightarrow$ side of folio 14. Then follow eight further (comparatively smaller) Christian poetical works of the fourth and fifth centuries - designated as P.Bodmer 30-37 - written on the remaining six leaves. They start on the $\downarrow$ side of folio 18, where there is also the ending of the Vision of Dorotheus: A Poem on Abraham (P.Bodmer 30), an Address to the Righteous (31), a Hymn to the Lord (32), Cain's Speech after Slaying Abel (33), a Christological poem (34), Abel's Speech after Being Slain by Cain (35), a poem with lacunose title (36), another hymn (37).

${ }^{19}$ Carlini, Papyrus Bodmer XXXVIII: Erma, Il Pastore, 12.

${ }^{20}$ Scribe $C$ then writes the Vision of Dorotheus and the Poem on Abraham, leaves 1418 (again, 12 and 13 are missing). Scribe D starts the Address to the Righteous on the 'verso' of leaf 18, and goes with it two more leaves, 19 and 20. Scribe E starts on leaf 20 and continues on 21, writing the Hymn to the Lord and Cain's Speech after Slaying Abel. Finally, scribe F writes the rest of the poems - the Christological poem, Abel's Speech
} 
pages written by scribe B - who writes the second part of Hermas - there is a minimum and maximum of 36 respectively 40 lines per page, and a minimum and maximum of 24 respectively 37 . Four pages would then have between 3456 and 5920 letters. Employing again the countingcharacters-with-no-spaces feature of the word processor on a modern edition, one will find that between the two values it is possible indeed to accommodate the rest of the fourth Vision (about 4050 characters) as Carlini estimates, but also the fifth Vision (adding up to about 5350 characters). Incidentally, this range can accommodate the first Mandate as well, which would add up to about 5700 characters.

Perhaps we can get even more specific than this. In the reconstruction offered by Carlini, scribe B wrote 1058 letters on the $\downarrow$ side of leaf 11, and 1340 letters on the $\rightarrow$ side of leaf 6 . The range obtained by multiplying each of these by four is narrower - 4232 and 5360 - but still wide enough to accommodate the fifth Vision. What is more, as Carlini does recognize, there is nothing in the extant manuscript to prevent the possibility that the codex included at the middle more than one folio; there are simply no palaeographical or codicological grounds to estimate how much of the Shepherd was in the initial codex. Again, such calculations are not meant to produce a new reconstruction, but to cast reasonable doubt that such precise a reconstruction as the beginning of the fifth Vision can withstand scrutiny. The main problem is, of course, the fact that this fifth Vision is a very short piece.

To conclude, the two manuscripts - P.Mich. 2.2.129 and P.Bodmer 38 cannot be taken as positive evidence for a divide before Vision 5 in the Egyptian transmission of the Shepherd.

\section{How Many Hermas Papyrus Fragments Can Be Paired?}

As is the case with other literary texts among the papyri, dismembered fragments of the same Hermas manuscripts have been published separately. For instance, P.Oxy. 50.3526 + P.Oxy. 9.1172 (LDAB 1105) are parts of the same codex, and so are - hosted now in altogether different

after Being Slain by Cain, the poem with lacunose title, and the final hymn - starting on leaf 21 and continuing on the remaining three leaves, 22-24. Cf. Kasser et al., "Nouvelle description du Codex des Visions," 107. 
collections - P.Prag. $1.1+$ P.Weill 1.96 (LDAB 1109) fragments of another codex.

This was also proposed in two other cases. Van Haelst notes, for instance, with regard to P.Amh. 2.190, "peut-être le même codex que celui du BKT 6.2.2., cf. 666." ${ }^{21}$ P.Amh. 2.190 (LDAB 1112) designates a group of ten fragments - lettered from $a$ to $k$, of which fragment $c$ is also P.Amh. 197 - which come from seven leaves of a papyrus codex; ${ }^{22} B K T$ 6.2.2 is P.Berol inv. 6789 (LDAB 1115), a fragmented bifolium of a papyrus codex, which when closed measures $14.5 \times 15.5 \mathrm{~cm}$, but the bottom with about three lines of text is lost. ${ }^{23}$ It must have been the middle bifolium of its gathering, as the text on the $\downarrow$ side continues from the left page to the right page. The editors of the latter already doubted the identification of this hand with that of P.Amh. 2.190. ${ }^{24}$ More recently, G.H.R. Horsley notices that Turner "estimates that the number of lines per page in P.Amh. 2.190 could be nearly twice as that for P.Berl. inv. 6789,25 which would point against the identification. Indeed, comparing the digital images which are now available, it is possible to verify that while the general aspect is quite similar, in both cases the script being Alexandrian majuscule - explaining the suggestion that they might be of the same codex - there are also differences, of which the most visible is perhaps the variation in stroke thickness in P.Amh. 2.190, especially compared to P.Berol inv. 6789, indicating a better trained scribe.

\footnotetext{
${ }^{21}$ J. van Haelst, Catalogue des papyrus littéraires juifs et chrétiens (Papyrologie 1; Paris: Publications de la Sorbonne, 1976), at 238.

${ }^{22}$ First published in B.P. Grenfell and A.S. Hunt, "CXC. Fragments of the Shepherd of Hermas," in B.P. Grenfell and A.S. Hunt, eds., The Amherst Papyri, Part II (London: Oxford University Press, 1901), 195-200. Digital images available at <http://corsair. themorgan.org/cgi-bin/Pwebrecon.cgi?BBID=350529>.

${ }^{23}$ First published by K. Schmidt and W. Schubart, "2. Sim. VIII, 1, *1-12. P. 6789," in BKT 6 (1910), 17-20. Digital images are available online at <http://ww2.smb.museum/ berlpap/index.php/01683/>.

${ }^{24}$ Schmidt and Schubart, "2. Sim. VIII, 1, *1-12. P. 6789,” 20.

${ }^{25}$ G.H.R. Horsley, New Documents Illustrating Early Christianity 2 (North Ryde: Macquarie University, 1982), 161, about E.G. Turner, The Typology of the Early Codex (Philadelphia: University of Pennsylvania Press, 1977), 131-132, tables entries 525 and 534.
} 
P.Amh. 2.190

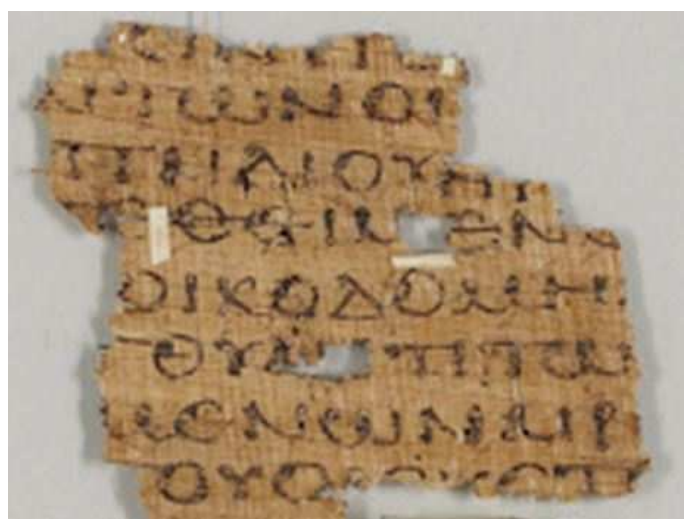

P.Berol inv. 6789

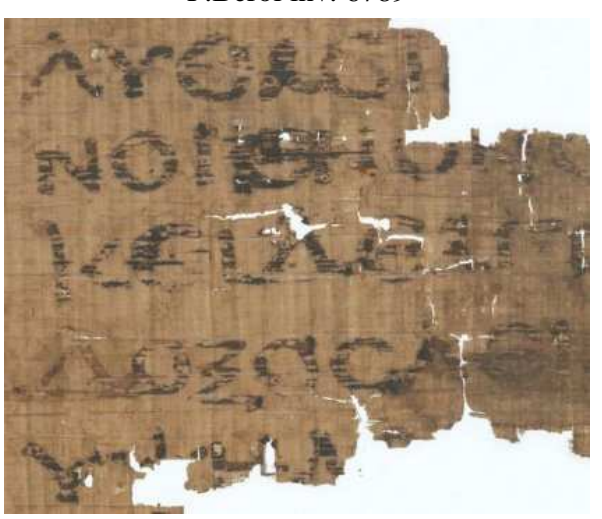

Still not settled, however, seems to be the case of P.Oxy. 15.1828 and P.Oxy. 15.1783. P.Oxy. 15.1828 (LDAB 1099) is a fragment of a vellum miniature codex,${ }^{26}$ published by its first editor, A. Hunt, as "Ethical Treatise." ${ }^{27}$ Three years later, S. Mercati identified it as a fragment of the Shepherd of Hermas and published a new edition in view of this discovery. ${ }^{28}$ P.Oxy. 15.1783 (LDAB 1103) too is a fragment of a miniature codex, written on both sides. ${ }^{29}$ It also seems e to be a

\footnotetext{
${ }^{26}$ Turner, Typology, 22 and 29-30.

${ }^{27}$ Grenfell and Hunt, Oxyrhynchus Papyri XV, 230.

${ }^{28}$ S.G. Mercati, "Passo del Pastore di Erma riconosciuto nel Pap. Oxy. 1828," Biblica 6 (1925), 336-338.

${ }^{29}$ First published in Grenfell and Hunt, Oxyrhynchus Papyri XV, 15-17.
} 
palimpsest; while the lower text remains illegible, ${ }^{30}$ the upper text is of the Shepherd of Hermas. L. Hurtado - perhaps via van Haelst? ${ }^{31}$ - notes that P.Oxy. 15.1783 may be part of the same codex with P.Oxy. 15.1828, and points out that they are dated to two different centuries, adding that "this illustrates the approximate nature of palaeographical dating, and how specialists can differ." ${ }^{32}$ A.M. Luijendijk also seems to accept this view, as in the list of Hermas papyri offered in n. 21 of her article on papyrus garbology the two appear as "P.Oxy. XV 1783 + P.Oxy. XV 1828," referring later on to Mercati's article, and conjecturing that since they are published in the same Oxyrhynchus Papyri volume "it is possible that both these vellum pieces came from the same tin box and thus the same general location in the garbage." 33

It should be pointed out that Mercati's suggestion was simply an open question ending his short article - "Non potrebbe forse appartenere all'altro frammento di Hermas, pure pergamenaceo, che porta il n. ${ }^{\circ} 1783$ ?" - and not an affirmation as a result of an analysis. In fact it is likely that Mercati suggested this without consulting either the papyri or their reproductions, since at least 1782 was not reproduced in its editio princeps. Given that online images of both papyri are now available, it is easy to verify that they are written by dissimilar hands, one rather upright, the other sloping uncial, as Hunt correctly described them. Indeed, G.H.R. Horsley, who also did not have access to the two papyri nor to reproductions, casted doubt on the proposal by comparing the two hand descriptions in the Oxyrhynchus Papyri $X V$ volume. ${ }^{34}$ By comparing the images it becomes clear that the formation of individual letters differs too, and not only the general aspect of the two hands. For instance o is written consistently large in 1783 and consistently small and above the baseline in

\footnotetext{
${ }^{30}$ Even more so today than in Hunt's time, who seems able to read seven words "with the aid of a reagent," Oxyrhynchus Papyri XV, 16. Wayment, The Text of Apocrypha, 155, suggests that this reagent might have rendered the fragment less readable.

${ }^{31}$ Van Haelst, Catalogue, at 662, mentioning Mercati, "Passo del Pastore," 338.

${ }^{32}$ L.W. Hurtado, The Earliest Christian Artifacts: Manuscripts and Christian Origins (Grand Rapids, MI/Cambridge: Eerdmans, 2006), n. 47 on page 23, and again in the table on page 224.

${ }^{33}$ A.M. Luijendijk, "Sacred Scriptures as Trash: Biblical Papyri from Oxyrhynchus," VC 64 (2010), 217-254, at 223 respectively 254. Wayment, The Text of Apocrypha, 156, may imply the same thing as he does not describe the hand of 1828 (as he would in most other cases) re-ferring instead to his notes on 1783; however, he retains the differing dating of the fragments so his take on the matter is unclear.

${ }^{34}$ Horsley, NDIEC 2, 160.
} 
1828 , and the left loop of the $\alpha$ is formed angularly in 1828 and rounder in 1783. Similarly, $\sigma$ and $v$ are clearly different in the two fragments. By categories, 1828's script-style is severe style sloping, whereas 1783 displays a rounder script, with no severe elements.
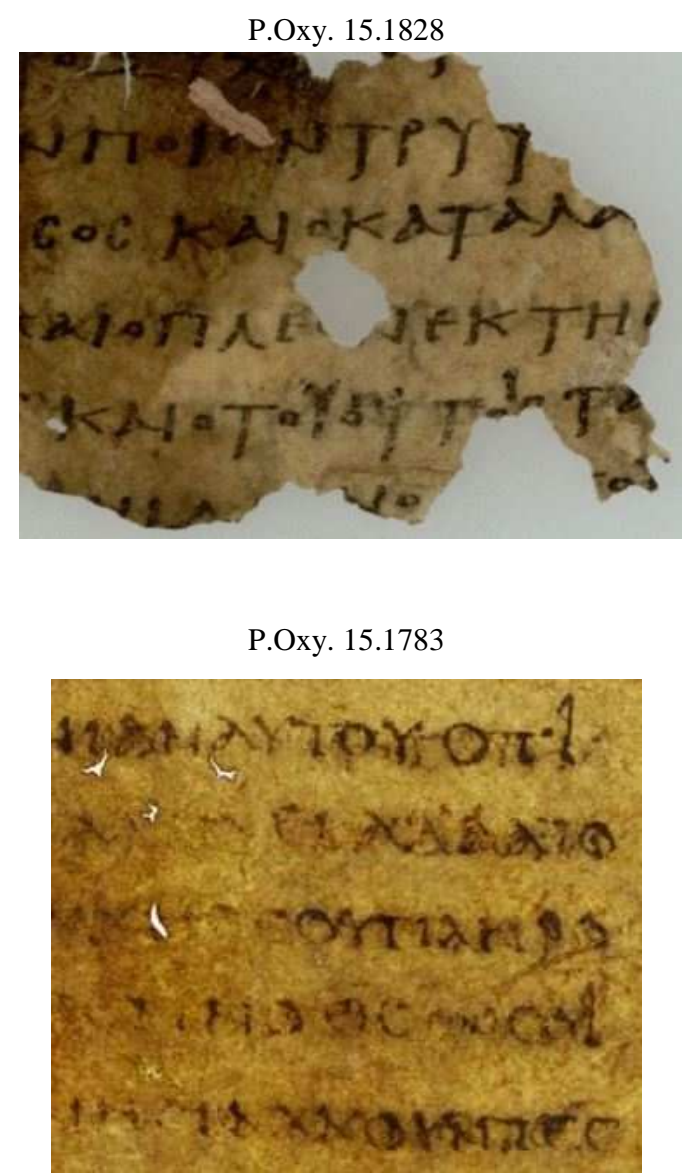

As such, there is no basis to consider P.Oxy. 15.1828 and P.Oxy. 15.1783 as part of the same manuscript.

To conclude, the complete list of the 23 Greek continuous papyri of the Shepherd known so far goes as follows: P.Iand. 1.4 (LDAB 1094), P.Oxy. 50.3528 (LDAB 1095), P.Oxy. 69.4706 (LDAB 10575), P. Oxy. 69.4705 (LDAB 10574), P.Mich. 2.2.130 (LDAB 1096), P.Oxy. 15.1828 (LDAB 
1099), P.Oxy. 50.3527 (LDAB 1098), P.Mich. 2.2.129 (LDAB 1097), P.Oxy. 69.4707 (LDAB 10576), P.Berol 5513 (LDAB 1100), P.Oxy. 3.404 (LDAB 1101), P.Berol 13272 (LDAB 1102), P.Oxy. 15.1783 (LDAB 1103), P.Oxy. 50.3526 + P.Oxy. 9.1172 (LDAB 1105), P.Oxy. 13.1599 (LDAB 1104), P.Hamburg inv. 24 (LDAB 1108), P.Bodmer 38 (LDAB 1106), P.Prag. 1.1 + P.Weill 1.96 (LDAB 1109), P.Berol 5104 (LDAB 1110), P. Harris 1.128 (LDAB 1111), P.Amh. Gr. 2.190 (LDAB 1112), P.Berol 6789 (LDAB 1115), and P.Berl. Sarischouli 9 (LDAB 1113). In addition, P. Oxy 1.5 (LDAB 2607) and P. Mich. inv. 6427 (LDAB 5694) contain possible quotations of the Shepherd embedded in other texts. 